\title{
Impact of microfinance on women's empowerment: a case study on two microfinance institutions in Sri Lanka
}

\author{
H. M. W. A. Herath ${ }^{*}$, L. H. P. Guneratne ${ }^{2}$ and Nimal Sanderatne ${ }^{3}$ \\ ${ }^{I}$ Department of Economics and Statistics, University of Peradeniya, Peradeniya, Sri Lanka. \\ ${ }^{2}$ Department of Agricultural Economics and Business Management, University of Peradeniya, Peradeniya, Sri Lanka. \\ ${ }^{3}$ Former Senior Visiting Fellow, Post Graduate Institute of Agriculture, University of Peradeniya, Peradeniya, Sri Lanka.
}

\begin{abstract}
This study investigates the impact of microfinance on poverty and socio-economic vulnerability of women and the ability to form social capital through group-based micro loans. The study uses four criteria to examine the impact of microfinance on poverty and vulnerability of women borrowers. The four criteria are, access, creation and control over private resources; freedom of decision making at home; self-confidence on socio-economic activities; and status in community and family. The study assumes that if these four variables have positively affected a woman, then she is empowered by microfinance received. The study uses three logistic regression models and a women's empowerment index to analyse women's empowerment. The logistic results revealed that the household income level before taking microcredit, age of the household head and market availability for products have been significant in affecting women's empowerment and reducing vulnerability. The disaggregated and overall Women Empowerment Indices (WEIs) clearly illustrate a considerable development after joining the microfinance institutions (MFIs). The analysis found that if the woman owned the loan and acted as a conduit of credit, it had a positive and significant impact on her ability to make decisions at home.
\end{abstract}

Keywords: microfinance, poverty and vulnerability reduction, women's empowerment, social capital

\section{BACKGROUND}

The discourse on microfinance traverses around several fields and interconnect with issues of economic globalisation and neoliberal policies, strategies for poverty and vulnerability reduction and pathways of empowerment of women. The provision of microfinance has been identified as a means of diversifying income earning opportunities, building financial and other assets and improving the socio-economic condition of poor, while strengthening crisis-coping mechanisms (Hashemi et al., 1996; Montgomery et al., 1996; Morduch, 1998; Husain, 1998). Sharma (2011) states that the access to credit via microfinance generates income and livelihood options for women and disadvantaged segments, giving more bargaining power within the household and contributes to family well-being. The Microcredit Summit held in Washington DC in 1997 identified four themes - reaching the poorest, the empowerment of women, building self-sufficient financial institutions and ensuring a positive and measurable impact on the lives of clients and their families.

Although, the impact of micro finance (MF) on the poor has been extensively examined over the past decade resulting in a large pool of source materials and literature, the impacts of MF on poverty reduction, especially on the vulnerability of women, have not been discussed at length. While some research work suggests that access to microfinance has the potential to reduce poverty significantly (Khandker, 1998), others argue that microfinance has minimal impact on poverty reduction (Morduch, 1998; Roodman \& Morduch, 2009). Poor women are particularly empowered by microcredit, as it gives them the ability to earn an income and thus improves their bargaining positions vis-à-vis their male partners (Gunathilake \& de Silva, 2010; Chang, 2010).

Morduch \& Haley (2002) argue that microfinance has proven to be an effective and powerful tool for poverty reduction. Further, the evidence shows that microfinance positively contributes to achieve the first six out of eight Millennium Development Goals. Robinson (2001) states that,

"among the economically active poor of the developing world, there is strong demand for 
small-scale commercial financial services - for both credit and savings. Where available, these and other financial services help low income people to improve household and enterprise management, increase productivity, smooth income flows and consumption cost, enlarge and diversify their micro business and increase their income".

According to Hossain's (1988) work on the Grameen Banks (GB);

"GB members had an income 43 per cent higher than the target group in the control villages, and about 28 per cent higher than the target group of non-participants in the project village".

Holcombe (1995), Remenyi (1997) Schuler et al.(1996) and Otero \& Rhyne (1998) also confirmed that microfinance brings about significant socio-economic benefits including increasing the income generation ability and reducing vulnerability of clients.

However, in the Sri Lankan context, in spite of the long history of microfinance with a large number of institutions providing microfinance services, particularly to the poorest households, there are only a limited number of research findings on the ways of approaching clients and their impact on reduction of poverty and vulnerability of the poor. Hewavitharana (1994), Dias (2001) and Mithrarathne (2003) have reviewed the progress of the Women's Development Federation (WDF), also known as Janashakthi Banks, in Hambantota. In a more rigorous analysis, Wickrama (1998) evaluates the Social Mobilization Programme in the Hambamtota district by using quantitative and qualitative data collected through a sample survey. Tilakaratna et al. (2005) have conducted a household survey on microfinance outreach and its impact on poverty, covering all districts except those in Northern and Eastern provinces. In another study, Ministry of Finance and Planning, Sri Lanka and German Technical Corporation (GTZ) (2008) have conducted a household survey on outreach of financial services in Sri Lanka; a look at the demand-side from a microfinance perspective covering all districts except those in the Northern province. Colombage et al. (2008) have conducted a case study of selected districts in Sri Lanka on effectiveness of microfinance in reducing rural poverty. The study assessed the outreach and impact of the microfinance industry in tackling rural poverty in Sri Lanka, taking into account a multitude of factors affecting the performance of microfinance clients and small enterprises. Gunathilake \& de Silva (2010) addressed the question of whether ownership of a microfinance loan increases women's empowerment. Most of those analyses have not considered the significance of social capital, providing group identity, solidarity and spaces for negotiation to alter gender relations.

\section{WOMEN'S EMPOWERMENT AND MICROFINANCE}

The empowerment concept tends to be primarily applied to disadvantaged groups of people, and is usually linked to a vision of more equal living conditions in society (Mishra \& Dale, 1996). Elliot (2008) suggests three closely related dimensions of empowerment; individual capabilities such as health, education, knowledge, selfconfidence, vision; institutional, cultural and other resources that provide opportunities and constraints; and agency or processes through which choices are made and put into effect. The concept of empowerment is being used increasingly as a tool for understanding what is needed to change the situation for women and other marginalised sections of society. Hulme \& Mosley (1996) stated that two forces, financial performance and aid donor's performance, are significant in increasing women's involvement in credit programmes. Amin et al. (1994), Naved (1994), Hashemi et al. (1996) and Pitt \& Khandekar (1998) investigated microfinance and the empowerment of women. Colombage et al. (2008) constructed Women's Empowerment Index (WEI) to examine the female participation in decision making for agricultural and non-agricultural activities.

Many researchers have produced empirical evidence that support the theoretically expected relationship between horizontal associations of people and economic benefits. They claim that grassroot organisations facilitate spontaneous cooperation. The participation in a rotating credit device or Self Help Group (SHGs) is significant as a member can earn a reputation for being honest and reliable by being a successful contributor and avoiding default. Hence, SHGs reflect how social capital facilitates collective actions and show how preexisting social connections mitigate barriers against collective action. Social capital of this kind is much more important for those who do not have access to formal credit markets. People who lack physical capital to offer as collateral effectively pledge their social connections. Therefore, people's associations can generate concrete monetary and economic benefits (Amunugama, 1964; Jayamaha, 1990; Dissanayake, 1991; Putnam, 1993).

The poor rely on social capital to a greater extent than the non-poor. However, the distributional effects of social capital are likely to be mixed, as some forms of social capital may assist the poor, whereas some other 
forms can limit their access to resources and information. Social interaction facilitates copying knowledge from those more knowledgeable, but the pooling of knowledge among a particular set of people can exclude the poor from knowledge. Against this background, it is worthwhile to investigate the relationship between social capital formation through microfinance intervention and its economic and non-economic outcomes on households.

This study fills this lacuna by investigating the impact on clients' level of socio-economic development considering poverty and vulnerability reduction, and social capital formation through group-based loans with Sarvodaya Economic Enterprise Development Services (Guarantee) Limited (SEEDS) and Thrift and Credit Cooperative Socities (TCCSs) in the Kandy District as case studies. Group based credit devices are common in the villages which are the subjects of this study; and they are analysed as potential sources of social capital and economic capital for households' empowerment. This research discusses the rationale, impact and evolution of thinking on microfinance as a tool in addressing issues of poverty, vulnerability and women's empowerment. It also explores the two interconnected arguments on microfinance, women and its potential for poverty and vulnerability reduction and women's empowerment:

- Whether microfinance as an approach reduces poverty and socio-economic vulnerability of women by generating income and creating livelihood options.

- Whether the institution of group-based loans as a collective process creates 'social capital' by providing group identity, solidarity and space for negotiation to alter gender relations.

\section{METHODOLOGY}

The study used two leading MFIs, SANASA (TCCSs) and Sarvodaya (SEEDS) operating in Kandy District, Sri Lanka, to study the different approaches of microfinance intervention and their impact on socioeconomic development of women. According to recent studies, Sri Lankan financial market is essentially a microfinance market with over $80 \%$ of households having total borrowings below Rs. 100,000 (Ministry of Finance and Planning, Sri Lanka \& GTZ, 2008). With the objective of fulfilling these small credit requirements, both minimalist and credit-plus approaches have been advocated by successive governments and NonGovernment Organizations (NGOs) on the role of poverty and vulnerability reduction. All these programmes are aimed at providing access to credit for poor including poor women at affordable interest rates. In addition to the government, a wide range of semiformal institutions, private institutions such as NGOs and some social institutions are also working in the sector. However, the achievements have been inadequate, especially in terms of reaching the small entrepreneurs for whom the programmes were designed, because these programmes included terms and conditions that were not favourable to the rural poor. Among these conditions were the collateral requirements from the institutions that made the loan beyond the reach of the women. Other problems associated with the programmes were lack of programme planning and clear-cut policy directives, small loan amount, lack of appropriate training and coordination among banks and line agencies. Having been driven from the formal credit markets due to these stringent conditions, poor entrepreneurs resort to borrowing from informal sources (Tilakaratna et al., 2005). This may affect the rating of formal sector financial services for micro-entrepreneurs.

Kandy district was selected for the study as it is one of the districts in Sri Lanka with a relatively high poverty rate (30.9\% in 1990 and $25 \%$ in 2002). World Health Organization's - Nutrition Country Profile for Sri Lanka (2000) indicates that around $26 \%$ of the people in Sri Lanka are undernourished. These persons are over represented in Kandy (52\%), Badulla (46\%), Monaragala (42\%), Nuwaraeliya (42) and Matale (40\%) districts. For this reason, many poverty alleviation programmes including several microfinance programmes have been implemented in this district, a fact that reflects the importance of microfinance as a strategy in poverty alleviation in Sri Lanka. Among them, the TCCSs and SEEDS provide their services to the needy people through an island wide established branch network. There were 125 active TCCS units and 108 SEEDS units in Kandy district by the end of 2007. However, in Kandy district the initiatives for microfinance projects seeking poverty and vulnerability reduction outcomes have had mixed results. In some programmes they have worked satisfactorily, while in some other instances they have not. As a result, the impacts on women's socioeconomic conditions have also been often mixed.

The methodology of this study is designed with the assistance on a framework developed by the SEEP Network $(2000)^{1}$ as part of the wider AIMS programme funded by the USAID. According to this conceptual framework, the household is the centre of its analysis. The reason is that small enterprises are closely linked with the household. Hence, it is theorised that microfinance exerts its impact at five levels. They are as follows; At the household level: small enterprises backed by 
microfinance contribute to increases in household income, asset accumulation and labour productivity. Increased income also leads to improvements in overall living condition of the family/households. At the enterprise level: microfinance leads to improvements in production, employment, assets and profits of small enterprises. At the individual level: microfinance has positive effects on individual income, decision making capacity, which in turn leads to strengthen the economic and social portfolio of the family/household. At community level (1): microfinance clients (enterprises) generate new employment opportunities and backward and forward linkage industries. Also attract new investment and income from outside the community. At community level (2): microfinance clients develop social capital. It leads to enhanced social empowerment, group lending, joint liabilities, networks, peer monitoring and progressive lending which enable poor to become bankable.

This study was mainly based on primary data that was collected from women households (microfinance clients) and selected MFIs, using a structured questionnaire. This was supplemented by several focus group discussions with local officials and key informants. Information by focus group discussions was mainly used for qualitative analysis of microfinance impact on women's empowerment. Secondary data was also gathered from institutional publications of the Central Bank of Sri Lanka, commercial banks, non-bank financial institutions, NGOs and other relevant agencies operating as MFIs in Sri Lanka. The questionnaire was designed with open and close ended questions according to the information needed to analyse the research objectives. Questions regarding household information, employment details, income data and information on microfinance intermediation achieved during the particular period as well as individual perceptions of existing MFIs were also included in the questionnaire.

The number of households selected from each institution/branch was proportionate to the approach which was being followed by the microfinance units. Out of the total number of clients (656) of TCCS units which followed minimalist approach, $5 \%$ were selected, while, from the total number of borrowers (2227) of TCCS units that followed credit-plus approach, $5 \%$ of borrowers were selected (111). Similarly, out of the total number, of clients (380) of SEEDS that followed minimalist approach, 5\% of borrowers (19) were included in the sample, while of the total number of borrowers of (2094) of SEEDS of credit-plus approach, 5\% (105) were included; thus making a total of 268 households in the sample (Table 1).

To analyse the poverty and vulnerability impact of microfinance services on women borrowers, a sub sample of women borrowers were separated from male borrowers. Accordingly, there were 119 women borrowers in the sample.

Several qualitative case studies conducted in the survey revealed how microfinance services provided by TCCSs and SEEDS have helped female clients to change their attitudes and to enhance their economic and social status within the family and community. It was expected to do a situation comparison before and after the credit facility taken by the households. The procedure/focused areas of the data collection are as follows;

- at individual level improvements/deterioration

- at family level improvements/deterioration

- business improvements/deterioration

- at community level improvements/deterioration

Following Mishra \& Dale (1996), Houssain et al. (2004) and Colombage et al. (2008), a Women's Empowerment Index (WEI) was constructed to analyse the impact of microfinance on women's empowerment quantitatively. Accordingly, it is assumed that women's power in decision making appears in four domains, namely agricultural activities, domestic affairs, business, and social affairs. Consequently, the researchers used rating values from the lowest value (1) to the highest value (5). At the lowest rating, women are least empowered while, at the highest rating they are most empowered. Thus, higher values reflect higher empowerment of women as follows;

$1=$ decision is made by other family members(out of household) in the absence of the husband;

$2=$ decision is made by the husband, when he is present, without consulting the wife;

3 = decision is made by the wife in the absence of the husband;

Table 1: Sample Selection

\begin{tabular}{lrrrrr}
\hline & Minimalist & \multicolumn{3}{c}{ Credit-plus } & Total \\
\hline & TCCSs & SEEDS & TCCSs & SEEDS & \\
\hline Total & 656 & 380 & 2227 & 2094 & \\
Sample (5\%) & 33 & 19 & 111 & 105 & $\mathbf{2 6 8}$ \\
\hline
\end{tabular}


$4=$ decision is made jointly by husband and wife, or jointly with others in the absence of the husband;

$5=$ decision is made by the wife, even when the husband is present.

Hence, the WEI for each domain is computed as follows;

Where;

$$
\mathrm{WEI}_{\mathrm{Ag}}=\frac{\sum_{\mathrm{i}=1}^{5}(\mathrm{Ag})_{\mathrm{i}}}{5} \quad ; \quad \mathrm{WEI}_{\mathrm{Do}}=\frac{\sum_{\mathrm{i}=1}^{5}(\mathrm{Do})_{\mathrm{i}}}{5}
$$

$$
\mathrm{WEI}_{\mathrm{Bu}}=\frac{\sum_{\mathrm{i}=1}^{5}(\mathrm{Bu})_{\mathrm{i}}}{5} \quad ; \quad \mathrm{WEI}_{\mathrm{Soc}}=\frac{\sum_{\mathrm{i}=1}^{5}(\mathrm{Soc})_{\mathrm{i}}}{5}
$$

$$
\begin{aligned}
& \mathrm{WEI}_{\mathrm{Ag}}=\text { WEI for agriculture } \\
& \mathrm{WEI}_{\text {Do }}=\text { WEI for domestic affairs } \\
& \mathrm{WEI}_{\mathrm{Bu}}=\text { WEI for business activities } \\
& \mathrm{WEI}_{\text {Soc }}=\text { WEI for social affairs }
\end{aligned}
$$

Thus, the overall WEI can be expressed as follows:

$$
\mathrm{WEI}=\frac{\mathrm{WEI}_{\mathrm{Ag}}+\mathrm{WEI}_{\mathrm{Do}}+\mathrm{WEI}_{\mathrm{Bu}}+\mathrm{WEI}_{\mathrm{Soc}}}{4}
$$

In addition to WEI, three single equation regression models were estimated with four criteria/determinants to analyse the poverty and vulnerability impact of microfinance services on women. Determinants of empowerment by microfinance services are access, creation and control over private resources (credit, savings and assets), freedom of decision making at home, self-confidence on socioeconomic activities and status in community and family (relationships, participation in village societies, social mobility). Based on these that criteria, the study assumed that; if these four variables have positively affected a woman, then it is assumed that she is empowered by microfinance services received. The variable definitions are given in Table 2. The description of the decision criteria was based on four aspects, namely, reducing vulnerability through asset creation, independence of decision making at home, self-confidence on socioeconomic activities and improvements of status in community and family.

Binary logistic single equation regression models were estimated to analyse women's empowerment. Accordingly, the logistic model for the study constructed stating that a household was empowered financially by MF services $(\mathrm{Y}=1)$ or otherwise $(\mathrm{Y}=0)$. For estimation purposes, the single equation Logit model is written as follows:

$$
\mathrm{L}_{\mathrm{i}}=\operatorname{In}\left[\frac{\mathrm{P}_{\mathrm{i}}}{1-\mathrm{P}_{\mathrm{i}}}\right]=\beta_{1}+\beta_{2} \mathrm{X}_{\mathrm{i}}+\mathrm{U}_{\mathrm{i}}
$$

Where,

$L=$ the $\log$ of the odds ratio.

$\mathrm{P}_{\mathrm{i}}=$ the probability of financial empowerment, where $\mathrm{Y}=1$.

$1-\mathrm{P}_{\mathrm{i}}=$ the probability of not financial empowerment, where $\mathrm{Y}=0$.

$\mathrm{X}=$ is a vector representing explanatory variables given in Table 2.

$\mathrm{U}_{\mathrm{i}}=$ is the random error term.

The difference between the three single equation models depends on usage of four criteria for the poverty and vulnerability impact analysis of microfinance services of women borrowers mentioned above. The first model assumes that if the four variables have positively affected a woman, then she is empowered

Table 2: Definitions of the explanatory variables

\begin{tabular}{ll}
\hline Variable & Definition \\
\hline Ybefore & Household's income level before taking microcredit (Rs.) \\
Distance & Distance to closest MFI (meters) \\
Cpemp & Cpemp $=1$ if credit plus services affected income empowerment, otherwise Cpemp =0 \\
Members & Number of family members in the household \\
Age & Age of the household head in years \\
Timeyrs & Duration in an microfinance programme (Number of years) \\
Intrestr & Rate of interest on credit (percentage) \\
Credit & Credit amount (Rs.) \\
Edu & Education level of the household head (No. of years of schooling) \\
Mkts & Markets $=1$ if markets are available for produce by micro enterprise, otherwise Markets $=0$ \\
FEowner & FEowner $=1$ if the household head is an owner of a micro enterprise when credit was taken, otherwise FEowner $=0$ \\
\hline
\end{tabular}


by microfinance services received. The second model assumes that if three criteria were positively affected, then the client is empowered. The third model assumes that if two criteria were fulfilled positively, the client is empowered.

\section{RESULTS AND DISCUSSION}

\section{Women's Empowerment Index}

Overall \& subdivision wise, WEIs clearly illustrate an improvement after joining the MFIs (Table 3). This supports the argument that microfinance enables women to improve their empowerment through reducing poverty and vulnerability. The decision making power is a very crucial factor in gender studies. If a woman is benefited by attaining power through microfinancial intervention, especially joining to a small group loan, then it is necessary to pay considerable attention on these findings by policy decision-makers. Colombage et al., (2008) also confirmed these positive achievements for women through group loans at high levels from their findings. This is a very supportive result that microfinance is significantly important for development of social capital among the group members, because this transaction is intentionally occurring between the group members. It is necessary to build up trust, friendship, reciprocity, networks and positive interactions among group members to achieve high-quality results individually as well as within the group. Therefore, it can be confirmed that both MFIs achieved their targets at satisfactory levels. and availability of markets for crop were the significant variables affecting women's empowerment and reducing vulnerability. However, the variables Ybefore and Age are significant at $10 \%$ level, while the variable Mkts is significant at $5 \%$ level. Household income level before taking microcredit negatively affects women's empowerment. The reason for this situation might be due to the following: this income is family income; there is no clear evidence regarding who controls the money before receiving microfinance; also it is not clear who earns this money. Then there is no power to use this money as the head of the household is female. Thus, the expected result of this variable is ambiguous.

The rest of the explanatory variables were not sinificant in determining women's empowerment and vulnerability reduction. Of the variables considered, access to the market is the prominent variable. Marginal effects of the variable indicate that if women respondents have enough market facilities for their products, the probability of empowerment and vulnerability reduction increase by $51 \%$. In other words, respondents who have the market facilities are able to be empowered by $51 \%$ relative to those who do not have market facilities. This indicates that availability and accessibility of markets are always significant factors affecting income and profit increases of any kind of micro enterprise. Similarly, if the household head's age is high, the probability of empowerment has a tendency to increase.

Model 2: All other factors remain unchanged except the status in community and family criteria. This criterion

Table 3: Women's Empowerment Indices

\begin{tabular}{lrrrrrrr}
\hline Activity & \multicolumn{3}{c}{ TCCSs } & \multicolumn{3}{c}{ SEEDS } & \multicolumn{3}{c}{ Both MFIs } & \% Difference \\
\hline & Before & After & Before & After & Before & After & \\
Agriculture & 3.75 & 3.98 & 3.99 & 4.01 & 3.87 & 4.00 & 3.36 \\
Domestic affairs & 4.21 & 4.35 & 4.60 & 4.62 & 4.40 & 4.49 & 2.04 \\
Enterprise & 3.41 & 3.88 & 3.42 & 4.43 & 3.41 & 4.16 & 2.20 \\
Social affairs & 3.12 & 3.22 & 3.56 & 3.60 & 3.34 & 3.41 & 2.10 \\
Overall & 3.62 & 3.86 & 3.90 & 4.17 & 3.76 & 4.02 & 2.60 \\
\hline
\end{tabular}

\section{Women's Empowerment Single Equation Logistic Models}

Three binary logistic regression models were estimated and the differences between the three models depended on the usage of four criteria for the analysis of poverty and vulnerability impact of microfinance on women. The results are presented in Table 4. As depicted, all the models have satisfactory goodness-of-fit.

Model 1: The results indicate that only household income level before taking microcredit, age of the household head has been omitted purposely from the regression analysis to see whether empowerment probabilities of explanatory variables have changed or not. Accordingly, access and control over private resources, freedom of decision making at home, self-confidence on socioeconomic activities are used as determinants of poverty and vulnerability reduction. If these three variables have positively affected a woman after the loan, then she is empowered by microfinance services received. All independent variables are the same as before. The dependent variable in this model is named as FEemp2new. 
According to the logistic results, the model is statistically significant. Confirming this situation, the results indicate that only age of the household head and market availability for products were significantly (at 10\% and 5\% levels respectively) affecting women's empowerment and reducing vulnerability. As in model 1 , the age of the household head is a significant variable in this model too. All other explanatory variables are not significant in determining women's empowerment and vulnerability reduction.

Model 3: All other factors remain unchanged except two decision criteria, self-confidence on socioeconomic activities and status in community and family. These determinants have been omitted purposely for the regression analysis to see whether empowerment probability has changed or not. All independent variables are the same as before. The dependent variable in this model is named as FEemp3. Logistic regression was estimated with 119 observations. According to the logistic results, the model is statistically significant. However, the results indicate that only market availability for products is the significant variable affecting women's empowerment and reducing vulnerability. All other explanatory variables are not statistically significant. Marginal effects of the variable demonstrate that if women respondents have enough market facilities for their products, the probability of empowerment and vulnerability reduction increases by $60 \%$. In other words, respondents who have the market facilities are able to be empowered by $60 \%$ relative to those who does not have market facilities.

\section{Qualitative Survey Findings on Women's Empowerment}

A number of qualitative case studies were carried out to examine how microfinance services provided by TCCSs

Table 4: Estimates of the binary logistic single equation models

\begin{tabular}{|c|c|c|c|}
\hline \multirow[t]{2}{*}{ Variable } & Model 1: DV- FEemp1 & Model 2: DV- FEemp2new & Model 3: DV- FEemp3 \\
\hline & Coefficient & Coefficient & Coefficient \\
\hline \multirow[t]{2}{*}{ Ybefore } & $-.0000847^{*}$ & -.0000544 & -.0000621 \\
\hline & $(.0000502)$ & $(.0000494)$ & $(.000048)$ \\
\hline \multirow[t]{2}{*}{ Distance } & -.0003991 & -.0003406 & -.0002325 \\
\hline & $(.0003647)$ & $(.0003728)$ & $(.0003349)$ \\
\hline \multirow[t]{2}{*}{ Cpemp } & .3238384 & .2236535 & -.2913357 \\
\hline & $(.6232492)$ & $(.6713099)$ & $(.6320816)$ \\
\hline \multirow[t]{2}{*}{ Members } & .406098 & .2981193 & .0502575 \\
\hline & $(.282796)$ & $(.3104971)$ & $(.2590748)$ \\
\hline \multirow[t]{2}{*}{ Age } & $.0510339 *$ & $.0621138 *$ & .0332347 \\
\hline & $(.0298027)$ & $(.0328229)$ & $(.0267108)$ \\
\hline \multirow[t]{2}{*}{ Timeyers } & .1177407 & .1948504 & .2252616 \\
\hline & $(.1701585)$ & $(.1920444)$ & $(.1761177)$ \\
\hline \multirow[t]{2}{*}{ Interstr } & .0289472 & -.0317077 & -.0150807 \\
\hline & $(.0617658)$ & $(.0672675)$ & $(.0588857)$ \\
\hline \multirow[t]{2}{*}{ Credit } & .0000111 & .0000163 & .00002 \\
\hline & $(.00000132)$ & $(.0000156)$ & $(.00000151$ \\
\hline \multirow[t]{2}{*}{ Edu } & .1352217 & .1659232 & .1409216 \\
\hline & $(.1483946)$ & $(.1599718)$ & $(.1369145)$ \\
\hline \multirow[t]{2}{*}{ Mkts } & $3.029121 * *$ & $3.614117 * *$ & $2.866808 * *$ \\
\hline & $(.8008109)$ & $(.8763752)$ & $(.7099104$ \\
\hline \multirow[t]{2}{*}{ FEowner } & .6788804 & -.1343146 & -.2836427 \\
\hline & $(.562554)$ & $(.6380226)$ & $(.5676683)$ \\
\hline \multirow[t]{2}{*}{ Intercept } & -8.623199 & -7.883023 & -4.69441 \\
\hline & $(3.227081)$ & $(3.480371)$ & $(2.714855)$ \\
\hline No. of observations & 119 & 119 & 119 \\
\hline Pseudo R2 & 0.4293 & 0.5122 & 0.4060 \\
\hline
\end{tabular}

Note: Standard errors are within parenthesis.

DV-Dependent Variable: a household has been empowered financially by MF services $(\mathrm{Y}=1)$ or otherwise $(\mathrm{Y}=0)$

** Significant at 5 percent level, * Significant at 10 percent level 
and SEEDS facilitated women to improve their attitudes, networks, trust and reciprocity, and to enhance their status within the family and community through social capital formation ${ }^{2}$. The procedure and the results of the analysis are as follows;

At individual level: Prior to joining the MFIs, the female borrowers were mostly confined to the traditional housewife's functions such as cooking, collecting fire wood, feeding and caring for children and housekeeping. They had poor self-confidence with this marginalised situation. They mainly depended on the husband's income or government subsidy and did not possess any savings. Male dominance was prevalent in family as well as in society. Men are considered by women, as well as by other men, as working harder and as the bread winners for their households. Women, on the other hand, are considered as supplementary earners. They are expected to do all the household work, until their female children start helping them. Men's participation in household work is found only in few cases, and is restricted to fetching water (if the source is far away) and chopping firewood for fuel. No choice is available with respect to what productive work women can do, as it is shaped by the norms on division of work between men and women. For instance, with respect to paddy cultivation, women are allowed to do only weeding, transplanting, and harvesting as per the division of labour; these tasks fetch lower wages than ploughing, carried out by men.

Focus group discussions also revealed that men have more leisure time than women. As soon as possible a man is free, he cycles or walks to a tea stall or a common place where other men gather. Women use their leisure time to sleep, listen to the radio or watch television and nothing beyond that. However, since joining the microfinance programmes, female clients have been able to improve their self-confidence and self-worth. Now they are more social and they have gained ability to express their ideas and views in public. They are engaged in incomegenerating activities and as a result they have more decision making power. Likewise, now they have little savings, but not as expected.

At family level: Before joining the microfinance programmes, rural women were basically attached to the traditional wife/mother role in the family, while the husband used to be the only wage earner if there were no young male members in the family. Thus, there was gender based division of labour in the family. Despite housework, the wife often supported her husband's income generating activities providing unpaid labour. Decision making on activities such as social, economic, cultural and any other kind was principally made by the husband or another male family member. A gradual change of these family relationships in favour of females can be observed after they joined the programmes. The group loans have given them the opportunity to broaden their possibilities beyond the traditional wife/mother role. Now they have interaction with others and engage in income generating activities. As a result, they have gained more bargaining and decision making power within the family.

However, still most of the rural women members think that men's contribution to work is more important than theirs, as it brings in greater revenues to the family. They do not value their (unpaid) housework. Women's control on wages and expenditure for personal consumption is very low. As women say, "We spend only for our homes". Men, on the other hand, spend on themselves and have higher control on expenditure. Women seem to have a fair amount of say on small household expenditure, but they have to take the consent of their husbands for major expenditure.

Business: As the poor rural women did not have access to formal financial institutions, they did not have any opportunity to initiate business enterprises before joining the TCCSs or SEEDS. As most of the rural women are not educated and myopic in their behavior, they lack entrepreneurship skills. Both TCCSs and SEEDS have provided opportunities for rural women to overcome these barriers through credit plus services such as skill development, training, educational activities, marketing assistance, supply of inputs and business development services. Borrowings, savings and other facilities provided through group loans by MFIs have enabled them to start their own business and improve the financial position.

Women's physical mobility has expanded by attending meetings and training programmes as well as through visits to banks. Enterprise activities have also contributed to enhanced mobility as they involve visits to local and distant markets. Some of the women members have travelled to villages and cities they had never seen before. Unlike in the past, they now travel without their husbands, either alone or with other women. Enhanced mobility and interaction has increased women's confidence, courage and access to knowledge and information. Futhermore, they have improved social capital such as trust, reciprocity and more ties/interactions among themselves. While men do not entirely support these changes, most do not object as economic benefits accumulate to the family. In some instances women have gone out on group meetings against the wishes of their husbands and sons.

At community level: Before joining the MFIs, the female borrowers did not have much relationship with the community. There was hardly any responsibility or 
consciousness towards the community. No cooperative efforts were made for community development. However, active relations with group members have led to a change in these circumstances enormously. Active participation in village level organisational activities and other community work has empowered women to build up their self-confidence, networks, reciprocity, attitudes and income generation capabilities.

Various credit-plus services such as awareness programmes and festivals conducted at the village level have enhanced collective conciseness and social harmony. The general opinion of most of the group members is, "we feel like one big family now, with greater unity among members". Similar type of socioeconomic relationship improvements through group loans can be pointed out from literature. Padia (2006) pointed out that in India, women's empowerment impact at the collective level has achieved greater benefits. Many cluster leaders are getting ready to participate in Panchayat elections, with the backing of the groups. Women, particularly leaders, are looking for their own space to make an impact so that they can be heard and can negotiate with the government. Panchayats at the local level now recognise 'kalanjiams' (Savings and Credit Self-Help Group in India) and invite the group leaders to attend Grama Sabha meetings. According to Padia (2006), in some villages, the Panchayat has provided the SHG with space for conducting meetings. In Grama Sabha meetings, SHG have taken up infrastructure issues such as access to electricity, drinking water facilities and roads.

\section{CONCLUSIONS AND POLICY IMPLICATIONS}

This study investigated the impact of microfinance on poverty and socio-economic vulnerability of women and social capital formation ability of group based micro loans. An investigation of this nature has critical implications for microfinance policy and practice, and also for policy related to gender equality. The study has used four criteria to examine the impact of microfinance on poverty and vulnerability of women borrowers. Determinants of empowerment by microfinance services are access, creation and control over private resources: freedom of decision making at home; self-confidence on socioeconomic activities; and status in community and family. The study assumed that if these four variables have positively affected a woman, then she is empowered by microfinance received.

Three binary logistic single equation regression models were estimated to analyse women's empowerment. According to the first logistic results, household income level before taking microcredit, age of the household head and markets availability for products were identified as significant variables affecting women's empowerment and reducing vulnerability. However, the results of the other two analyses indicated that only availability of markets for products was the significant variable affecting women's empowerment. Women respondents who have the market facilities are empowered by $60 \%$ relative to those who do not have market facilities. This indicates that availability and accessibility of markets are always a significant factor for income and profit increases of any kind of enterprise. Among the other variables contributing significantly and positively towards empowerment were age level of household head - with higher age leading to greater empowerment; and household's income level before taking micro loan, no doubt proxying enough capital for the new or existing enterprise.

The factors found to have a negative impact on empowerment were distance to the closest MFI, credit plus services, number of family members in the household, number of years the credit has been taken, rate of interest on credit, credit amount, education level of the household head, ownership of a micro enterprise. These are interesting socio-economic factors and effects which merit further research.

According to the WEI which was constructed to analyse the impact of microfinance on women's empowerment, women's power in decision making was estimated in four domains, namely, agricultural activities, domestic affairs, business, and social affairs. The divisional and overall WEIs clearly illustrate a considerable development after joining the MFIs. The analysis found that if the woman owned the loan and acted as a conduit of credit, it had a positive and significant impact on her ability to take decisions about the use of credit, management of the project, control of purchases of inputs and marketing of final products, ability to retain income and make decisions about project income and ability to contribute to making decisions about the future of the business.

This is supportive of the argument that microfinance enables women to improve their empowerment through reducing the poverty and vulnerability. Survey results reveal that microfinance has the potential to empower its clients/women, by providing them with self-reliance, self-confidence, self-worth and decision making powers through interaction with the group members and the rest of the community. Furthermore, this supports the result that microfinance is significant for the development of social capital such as trust, reciprocity, networks and 
positive interactions among the group members because this transaction is intentionally occurring between group members.

However, as revealed in the qualitative survey, factors such as unprofessional business practices, lack of economies of scale, clients' risk aversion and myopic behavior, inadequate technological and business guidance on new products, non availability of input resources, lack of research and development initiatives and lack of innovation have restricted the growth of small enterprises supported by microfinance services. The adverse natural environment, poor infrastructure and lack of markets for products and weak market linkages and networks have further worsened the profitability and sustainability of these small enterprises.

The empirical evidence derived from the study exemplifies the importance of concentrating on women's empowerment as a part of the socio-economic assignment of microfinance. Donors and financiers of funds to MFIs have begun to look at the 'dual base line' and monitor how an MFI is meeting its socio-economic objectives whilst meeting financial viability and sustainability. It is anticipated that the findings of this study will persuade them to focus their attention again on the important socioeconomic benefits that women's access to microfinance offers, with a view to formulate an enabling policy framework.

\section{END NOTES}

1 The Small Enterprise Education and Promotion (SEEP) Network is an association of more than Forty U.S. and Canadian NGOs that work with hundreds of local organisations on microfinance development. SEEP engages in research, documentation, and training activities aimed at improving member practice. Since its inception, SEEP has focused on monitoring and evaluation issues as a critical part of its programme; its Evaluation Working Group facilitates SEEP's work under the Assessing the Impact of Microenterprise Services (AIMS) project.

${ }^{2}$ This survey was especially conducted for the collection of information from group loans.

\section{REFERENCES}

Amin, S. \& Pebley, A. (1994) Gender inequality within households: the impact of a women's development programme in 36 Bangladeshi villages, in S. Amin ed. The Bangladesh Development Studies 'Special Issue on Women, Development and Change, XXII( 2\&3), pp: 121-155, BIDS: Dhaka.
Amunugama, S. (1964) Rural credit in Ceylon: some sociological observations, The Ceylon Journal of Historical and Social Studies, 7(2) (July- December), pp: 135-143.

Chang, H. J. (2010) 23 Things They Don't Tell You about Capitalism, London: Penguin Books Ltd.

Colombage, S. S., Ahmad, A. \& Chandrabose, A. S. (2008) Effectiveness of microfinance in reducing rural poverty: a case study of selected districts Sri Lanka, VISTAS, Journal of Humanities and Social Sciences, 4, pp: 1-37.

Dias, D. H. (2001) A women's organization for the development of women by women, Hambantota: Women's Development Federation.

Dissanayake, H. B. (1991) The role of NGOs in the microenterprise sector: approaches to development: the NGOs experience in Sri Lanka, Colombo: Agrarian Training and Research Institute.

Elliot, C. M. (2008) Introduction in 'Global Empowerment of Women: Responses to Globalization and Political Religions', New York, London: Rutledge, Taylor and Francis Group, pp: $1-21$.

Gunathilake, R. \& de Silva (2010) Microfinance and women empowerment, the impact of loan ownership on women's empowerment in microfinance households in Sri Lanka, Colombo: Centre for Women's Research (CENWOR).

Hashemi, S. M., Schuler, S. R. \& Riley, A. P. (1996) Rural credit programmes and women's empowerment in Bangladesh, World Development, 24, pp: 635-653 DOI: http://dx.doi.org/10.1016/0305-750X(95)00159-A

Hewavitharana, B. (1994) Build up a bank and grow with it, Hambantota:Women's Development Federation.

Holcombe, S. (1995) Managing to empower: the Grameen Bank's experience of poverty alleviation, London: Zed Press.

Hossain, M., Bose, M. L. \& Ahamad, A. (2004) Nature and impact of women's participation in economic activities in rural Bangladesh: insights from household survey, Scandinavian Working Papers in Economics, Lund University, No. 2004:20.

Hossain M. (1988) Credit for alleviation of rural poverty: the Grameen Bank in Bangladesh, Washington DC: IFPRI.

Hulme, D. \& Mosley, P. (1996) Finance for the poor, impacts on poverty, vulnerability and deprivation, in D. Hulme \& P. Mosley, Finance against Poverty, Vol. 1\&2, pp: 105-137, Rutledge: London.

Husain, A. M. (1998) Poverty alleviation and empowerment: the second impact assessment study of BRAC's rural development programme, Dhaka: BRAC publications.

Jayamaha, R. (1990) Innovative approaches to poverty alleviation through banking and financial institutions: a case for Sri Lanka, Staff Studies, 20 (1\&2), pp: 29-39. 
Khandker, S. R. (1998) Fighting poverty with micro credit: experience in Bangladesh, Washington DC: Oxford University Press, for the World Bank.

Ministry of Finance and Planning \& GTZ (2008) Outreach of financial services in Sri Lanka: a look at demand-side from a microfinance perspective, Sri Lanka, Colombo: German Development Cooperation.

Mishra, S. \& Dale, R. (1996) A model for analyzing gender relations in two tribal communities in Orissa, India, AsiaPacific Journal of Rural development, 4(1).

Mithrarathne, W. G. (2003) A success story for courage and determination: Janashakthi-story of thirteen years of endeavour, Hambantota: Women's Development Federation.

Montgomery, R., Bhattacharya, D. \& Hulme, D. (1996) Credit for the poor in Bangladesh, in D. Hulme \& P. Mosley eds. Finance against Poverty, London: Routledge.

Morduch, J. (1998) Does microfinance really help the poor? New evidence from flagship programs in Bangladesh. Research Programme in Development Studies, Wardrow School of Public and International Affairs.

Morduch, J. \& Haley B. (2002) Analysis of the effects of microfinance on poverty reduction, NYU Wagner Working Paper No. 1014, The Canadian International Development Agency, Canada.

Naved, R. (1994) Empowerment of women: listening to the voices of women, in S. Amin ed. The Bangladesh Development Studies 'Special Issue on Women, Development and Change', XXII(2\&3), pp: 121-179, Dhaka: BIDS.

Otero,M. \& Rhyne, E. (1994) The New World of Microfinance, West Hartford, CT:Kumarian Press

Padia, V. (2006) Social mobilization and micro-credit for women's empowerment: a study of the DHAN Foundation, in N. Burra, J. Deshmukh-Ranadive, \& R. K. Murthi eds. MicroCredit, Poverty and Empowerment, Linking the Triad, New Delhi/Thousand Oaks/London: SAGE Publications.
Pitt, M. M. \& Khandker, S. R. (1998) The impact of group-based credit programmes on poor households in Bangladesh: does the gender of participants matter?, Journal of Political Economy, 106, pp: 958-995. DOI: http://dx.doi.org/10.1086/250037

Putnam, R. D. (1993) The prosperous community: social capital and public life, American Prospect Outline.

Remenyi, J. (1997) Microfinance: a panacea for poverty?, Dublin: Centre for Development Studies, University College.

Rhyne, E. (1998) The Yin and Yang of microfinance: reaching the poor and sustainability, Micro Banking Bulletin.

Robinson, M. (2001) The microfinance revolution: sustainable finance for the poor, Washington DC: World Bank. DOI: http://dx.doi.org/10.1596/0-8213-4524-9

Roodman, D. \& Morduch, J. (2009) The impact of microcredit on the poor in Bangladesh: revisiting the evidence, Working paper, No. 174, Washington DC: Centre for Global Development.

Schuler, S. R, Hashemi, S. M. and Riley. A. P. (1996) Rural credit programs and women's empowerment in Bangladesh, World Development., 24(4), pp: 635-53. DOI: http://dx.doi.org/10.1016/0305-750X(95)00159-A

Sharma, K. (2011) Small loans, big dreams: women and microcredit in a globalizing economy, Review of Women's Studies, New Delhi: Centre for Women's Development Studies.

Tilakaratna, G., Wickramasinghe, U. \& Kumara, T. (2005) Microfinance in Sri Lanka: a household level analysis of outreach and impact on poverty, Poverty and Social welfare Series, No. 7, Institute of Policy Studies of Sri Lanka.

Wickrama, K. A. S. (1998) Group-based financial intermediation as a strategy for poverty alleviation: accomplishments, constraints and potentials - the social mobilization programme in the Hambantota district, Sri Lanka, Hambantota: Social Mobilization Foundation.

World Health Organization (2000) Nutrition Country Profile for Sri Lanka. 